\title{
Prolonged Impairment of Very Late Activating Antigen-mediated T Cell Proliferation via the CD3 Pathway after T Cell-depleted Allogeneic Bone Marrow Transplantation
}

\author{
Kanji Sugita, Yoshihisa Nojima, Kouichi Tachibana, Robert J. Soiffer, Christine Murray, Stuart F. Schlossman, \\ Jerome Ritz, and Chikao Morimoto \\ Division of Tumor Immunology, Dana-Farber Cancer Institute, Department of Medicine, Harvard Medical School, Boston, \\ Massachusetts 02115
}

\begin{abstract}
One of the major obstacles in allogeneic bone marrow transplantation (allo-BMT) is prolonged $\mathbf{T}$ cell dysfunction resulting in a variety of infectious complications in the months to years after hematologic engraftment. We previously showed that immobilized extracellular matrix (ECM) proteins such as fibronectin (FN), the CS-1 domain of FN, or collagen (CO) acted synergistically with immobilized antiCD3 to induce $T$ cell proliferation. In addition, the comitogenic effect of ECMs could be mimicked by immobilized mAb reactive with a common $\beta 1$ chain $(C D 29)$ of very late activating (VLA) antigens which include ECM receptors. Since the interaction of $T$ cells with ECMs appears to play an important role in the process of $T$ cell reconstitution following allo-BMT, we examined the expression of VLA antigens $(\alpha 1-\alpha 6, \beta 1)$ and their functional roles in CD3mediated $T$ cell proliferation at various times after $T$ cell depleted allo-BMT. VLA $\beta 1$ as well as VLA $\alpha 4$, $\alpha 5$, and $\alpha 6$ expression was lower than normal controls during the first 3 mo after allo-BMT and auto-BMT, whereas these expressions returned to normal levels by 4 mo after allo-BMT and auto-BMT. Although $\alpha 1$ and $\alpha 2$ were not expressed on lymphocytes from normal controls, these antigens were expressed on lymphocytes at the detectable levels (5-15\%) from patients after allo-BMT and auto-BMT. Both CD29 and $\mathrm{CD3}$ were expressed at normal levels on lymphocytes from patients $>\mathbf{3}$ mo after allo-BMT, whereas $T$ cell interaction with ECM through VLA proteins or crosslinking of VLA $\beta 1$ expressed by $T$ cells with anti-CD29 $\mathrm{mAb}$ results in poor induction of $\mathrm{CD3}$-mediated $\mathrm{T}$ cell proliferation for a prolonged period ( $>1$ yr) after allo-BMT. In contrast, $T$ cell proliferation induced by crosslinking of anti-CD2 or anti-CD26 with anti-CD3 was almost fully recovered by 1 yr post-allo-BMT. After autologous BMT, impaired VLAmediated $T$ cell proliferation via the $\mathrm{CD3}$ pathway after auto-BMT returned to normal levels within 1 yr despite no significant difference in CD3 and CD29 expression following either allo- or auto-BMT. The adhesion of $T$ cells from post-
\end{abstract}

Address correspondence to Chikao Morimoto, M.D., Division of Tumor Immunology, Dana-Farber Cancer Institute, 44 Binney Street, Boston, MA 02115.

Received for publication 8 September 1993 and in revised form 18 March 1994.

J. Clin. Invest.

(C) The American Society for Clinical Investigation, Inc.

0021-9738/94/08/0481/08 \$2.00

Volume 94, August 1994, 481-488
allo-BMT patients to FN-coated plate was normal or increased compared to that of normal controls. Moreover, the induction of the tyrosine phosphorylation of pp105 protein by the ligation of VLA molecules was not impaired in alloBMT patients. These results suggest that there are some other defects in the process of VLA-mediated signal transduction in such patients. Our results imply that disturbance of VLA function could explain, at least in part, the persistent immunoincompetent state after allo-BMT and may be involved in susceptibility to opportunistic infections after alloBMT. (J. Clin. Invest. 1994. 94:481-488.) Key words: VLA antigen • allo-BMT • CD3 pathway • extracellular matrix proteins $\cdot$ tyrosine phosphorylation

\section{Introduction}

Allogeneic bone marrow transplantation (allo-BMT) ${ }^{1}$ has been shown to provide potentially curative therapy for patients with a variety of diseases including many hematologic malignancies $(1,2)$. However, one of the major obstacles in allo-BMT is prolonged $\mathrm{T}$ cell dysfunction resulting in a variety of infectious complications in the months to years after hematological engraftment (3-5). Previous studies have documented a variety of in vitro $\mathrm{T}$ cell dysfunctions after allo-BMT, including impaired ability to provide help to B cell immunoglobulin synthesis, poor proliferative response to mitogenic stimuli, and abnormal function of cytotoxic effector cells (6-10). Moreover, these impaired in vitro $\mathrm{T}$ cell functions have been shown to continue for several years $(8,10)$, suggesting that these $T$ cell dysfunction(s), as yet uncharacterized, may contribute to increased susceptibility to opportunistic infections.

Adhesion molecules on $\mathrm{T}$ cells have attracted increasing attention because of the diverse roles that these structures play in many vital cell functions including differentiation, recirculation, antigen recognition, activation, and proliferation $(11,12)$. Based on their biochemical structure, lymphocyte adhesion molecules have been classified into three broad categories: the immunoglobulin, integrin, and selectin families (11). The very late activating (VLA) antigens constitute the $\beta 1$ integrin subfamily (13), and are one of the major adhesion receptors expressed by $\mathrm{T}$ cells. They are transmembrane glycoproteins consisting of a common $\beta 1$ subunit (CD29) nonconvalently associated with distinct $\alpha$ chains to form different heterodimers (12). The VLA proteins function as cell surface receptors mediating cell-cell

1. Abbreviations used in this paper: allo-BMT, allogeneic bone marrow transplantation; AML, acute myelogenous leukemia; $\mathrm{CO}$, collagen; ECM, extracellular matrix; FN, fibronectin; DFCI, Dana-Farber Cancer Institute; LN, laminin; MFI, mean fluorescence intensity. 
and cell-extracellular matrix protein (ECM) adhesive interactions. Recent studies have clearly shown that the VLA molecules not only mediate $T$ cell adhesion, but can synergize with the CD3/TCR pathway to promote T cell proliferation (14-19). Coimmobilization of ligand proteins of the VLA receptor family and submitogenic doses of anti-CD3 result in strong $\mathrm{T}$ cell proliferation through at least five receptor/ligand interactions: VLA-3/collagen, VLA-4/CS1 region of fibronectin (FN), VLA4/VCAM-1, VLA-5/RGD sequence of FN, and VLA-6/laminin. This comitogenic effect of ECM can be mimicked by immobilized $\mathrm{mAb}$ (anti-4B4) reactive with a common $\beta 1$ chain (CD29) (20). Moreover, we showed that the engagement of VLA molecules by specific antibodies or by their ligands rapidly stimulated tyrosine phosphorylation on a $105-\mathrm{kD}$ protein (pp105) in $\mathrm{T}$ cells (21). Furthermore, it has been proposed that the interaction of CD4- CD8- (double negative) immature thymocytes with FN expressed on thymic stromal cells via the VLA-4 and VLA5 receptors plays a crucial role in the differentiation of thymocytes $(22,23)$. The interactions of T cells with ECM thus could play an important role in normal $\mathrm{T}$ cell differentiation and may also play an important role in the process of $\mathrm{T}$ cell reconstitution after BMT.

In this paper, we examined the expression of VLA antigens $(\alpha 1-\alpha 6, \beta 1)$ and their functional roles in CD3-mediated $\mathrm{T}$ cell proliferation at various times after $\mathrm{T}$ cell-depleted allo-BMT, to determine whether VLA molecules are involved in prolonged T cell dysfunction after allo-BMT. We found $\mathrm{T}$ cell interactions with ECM through VLA proteins or crosslinking of VLA $\beta 1$ with anti-CD29 mAb result in poor induction of CD3-mediated $\mathrm{T}$ cell proliferation for a prolonged period $(>1 \mathrm{yr})$ after alloBMT despite almost normal CD3 and CD29 expression. This prolonged impaired function of VLA antigens appears to be due to some other defects in the process of VLA-mediated signal transduction, since the adhesion of $\mathrm{T}$ cells from post alloBMT patients to FN-coated plates was normal or increased and the induction of tyrosine phosphorylation of pp105 was not impaired. Thus, abnormal VLA function could explain, at least in part, the persistent immunodeficient state after $\mathrm{T}$ cell-depleted allo-BMT and may be involved in susceptibility to opportunistic infections in such patients.

\section{Methods}

Patients and samples. This study is based on the analysis of 38 patients who underwent allo-BMT over a 4-yr period at Dana-Farber Cancer Institute (DFCI). 16 patients had acute myelogenous leukemia (AML), 5 had acute lymphocytic leukemia, 15 had chronic myeloid leukemia, and 2 had other hematologic malignancies. Ages ranged from 18 to $58 \mathrm{yr}$ (median, 36). The preparative regimens of allo-BMT have been described previously $(24,25)$. The donor bone marrow was obtained from HLA identical siblings that were mixed lymphocyte cultures (MLC) nonreactive. The harvested marrow cells were treated with anti$\mathrm{CD6} \mathrm{mAb}$ (T12, IgM) and rabbit complement before infusion to deplete mature $\mathrm{T}$ cells as described previously (24). None of the patients included in this analysis developed moderate or severe graft versus host disease (GVHD) (grade II to IV), and none were receiving any immunosuppressive therapy. Auto-BMT patients $(n=12)$ were also analyzed in the same comparative studies. Informed consent was obtained from all patients. Peripheral blood was obtained at various intervals after BMT. A total of 60 samples from allo-BMT patients and 25 samples from auto-BMT patients were analyzed. A total of 30 samples from age and sex-matched healthy volunteers were used as normal controls.

Monoclonal antibodies and reagents. $\mathrm{mAb}$ reactive with $\mathrm{CD} 2\left(\mathrm{~T} 11_{1}\right.$,
IgG), CD3 (RW28C8, IgG1; OKT3, IgG2A), CD26 (1F7, IgG1), CD29 (VLA- $\beta 1$; 4B4, IgG1), CD49d (VLA- $\alpha 4$; 8F2, IgG1), CD49e (VLA$\alpha 5 ; 2 \mathrm{H} 6, \mathrm{IgG} 1$ ), and L-selectin (TQ1, IgG1) were produced in our laboratory and their characterization has been described elsewhere (14, 18, 26-29). Anti-CD49a mAb (VLA- $\alpha 1$; TS2/7, IgG1) was a kind gift from Dr. Martin E. Hemler (Dana-Farber Cancer Institute) (12). mAb reactive with CD49b (VLA- $\alpha 2$; G19, IgG1), CD49c (VLA- $\alpha 3$; P1B5, IgG2a), and CD49f (VLA- $\alpha 6$ : GoH3, rat IgG2a) were purchased from Amac Inc. (Westbrook, ME) and Oncogene Science Inc. (Manhasset, NY), respectively. Anti-phosphotyrosine mAb (4G10, IgG2) was purchased from UBI Laboratories (Lake Placid, NY). Anti-CD2, CD3, $\mathrm{CD} 26, \mathrm{CD} 29$, and L-selectin $\mathrm{mAb}$ used in proliferation studies were purified from ascites using protein A-agarose beads (Bio-Rad Labs., Richmond, CA). Human extracellular matrix proteins (ECM) such as fibronectin (FN), laminin (LN), and type I collagen (CO) were obtained from Telios Pharmaceuticals Inc. (San Diego, CA).

Phenotypic analysis. PBMC were obtained from peripheral blood samples by Ficoll-Hypaque density gradient sedimentation. PBMC were incubated at $4^{\circ} \mathrm{C}$ with a panel of mAbs for $30 \mathrm{~min}$. Cells were subsequently washed twice and incubated at $4^{\circ} \mathrm{C}$ with FITC-conjugated goat anti-mouse Ig (Tago, Inc., Burlingame, CA). Reactivity of mAbs was analyzed on the gated lymphocyte populations using an Epics-C flow cytometer (Coulter Corp., Hialeah, FL) as described previously (30).

Preparation of anti-CD3 mAb plus additional antibodies or ECMcoated plates. $100 \mu \mathrm{l}$ of purified anti-CD3 $\mathrm{mAb}$ at $0.1 \mu \mathrm{g} / \mathrm{ml}$ in PBS was plated in each well of a 96-well of flat-bottomed plate (Costar Corp., Cambridge, MA) and then incubated for $3 \mathrm{~h}$ at room temperature as described $(14,15)$. After washing twice with PBS, $100 \mu \mathrm{l}$ of PBS containing the indicated amounts of additional mAbs (anti-CD2, CD26, CD29, or L-selectin) or ECM (FN, CO, or LN) were then plated in each well and incubated for $3 \mathrm{~h}$ at room temperature. Before use wells were washed three times with PBS.

Proliferation assays. Lymphocytes were obtained from PBMC by depletion of contaminating monocytes by adherence to plastic plates. Further removal of monocytes was achieved by incubation with $5 \mathrm{mM}$ L-leucine methyl ester $\mathrm{HCl}$ as described $(14,15)$. The lymphocyte populations thus obtained were cultured at $37^{\circ} \mathrm{C}$ in triplicate wells at a concentration of $10^{5}$ cells/well in a serum-free medium consisting of Iscove's MEM supplemented with $0.1 \%$ BSA, $30 \mu \mathrm{g} / \mathrm{ml}$ human transferrin, $10 \mu \mathrm{g} / \mathrm{ml}$ soybean lipids, $50 \mu \mathrm{g} / \mathrm{ml}$ cholesterol, $4 \mathrm{mM}$ L-glutamine, $25 \mathrm{mM}$ Hepes buffer (Microbiological Assoc. Inc., Rockville, MD), $0.5 \%$ sodium bicarbonate, and $50 \mu \mathrm{g} / \mathrm{ml}$ gentamicin sulfate (Schering, Kenilworth, $\mathrm{NJ})$ as described $(14,15)$. After $3 \mathrm{~d}$ in culture, each well was labeled with $1 \mu \mathrm{Ci}$ of $\left[{ }^{3} \mathrm{H}\right]$ thymidine (ICN Radiochemicals, Irvine, $\mathrm{CA}$ ) for $18 \mathrm{~h}$. Cells were then harvested on a PHD cell harvester (Cambridge Technology, Cambridge, MA), and $\left[{ }^{3} \mathrm{H}\right]$ thymidine incorporation was measured with a $\beta$ scintillation counter.

Cell adhesion assays. Cell adhesion assays were performed as described previously (18). In brief, 96-well microtiter plates were incubated with $100 \mu \mathrm{l}$ of FN ( $10 \mu \mathrm{g} / \mathrm{ml}$ in PBS) for $3 \mathrm{~h}$ at room temperature, followed by incubation with heat-treated $\left(10 \mathrm{~min}\right.$ at $\left.80^{\circ} \mathrm{C}\right)$ BSA $(5 \mu \mathrm{g} /$ $\mathrm{ml}$ in PBS) for $2 \mathrm{~h}$ and washing with PBS. Plates coated with heattreated BSA alone were also prepared for controls. The lymphocyte population depleted of monocytes obtained as described in proliferation assays was labeled with $\left[{ }^{51} \mathrm{Cr}\right]$ sodium chromate (New England Nuclear, Boston, MA) for $1 \mathrm{~h}$ before adhesion assays, and then plated in triplicate on FN-coated plates and BSA alone-coated plates, and incubated for $1 \mathrm{~h}$ at $37^{\circ} \mathrm{C}$. The unbound cells were removed by gentle washing with PBS. The bound cells were lysed with $1 \%$ Nonidet P-40, and the cell lysates was analyzed using a $\gamma$ scintillation counter. The percent specific binding was calculated as follows: [(cpm of FN-coated plate)/cpm of BSA alone-coated plate)/cpm of total cells plated] $\times 100$.

Tyrosine phosphorylation studies. The monocyte-depleted lymphocyte populations obtained from three patients 6 mo after allo-BMT and a normal volunteer were analyzed. The cells $\left(5 \times 10^{6} \mathrm{cells} / 1 \mathrm{ml} / \mathrm{sample}\right)$ were resuspended in Iscove's serum-free media, and either left as controls or incubated with anti-CD29 mAb $(10 \mu \mathrm{g} / \mathrm{ml})$ for $15 \mathrm{~min}$ at $4^{\circ} \mathrm{C}$. After washing once with cold media, the cells were incubated with 

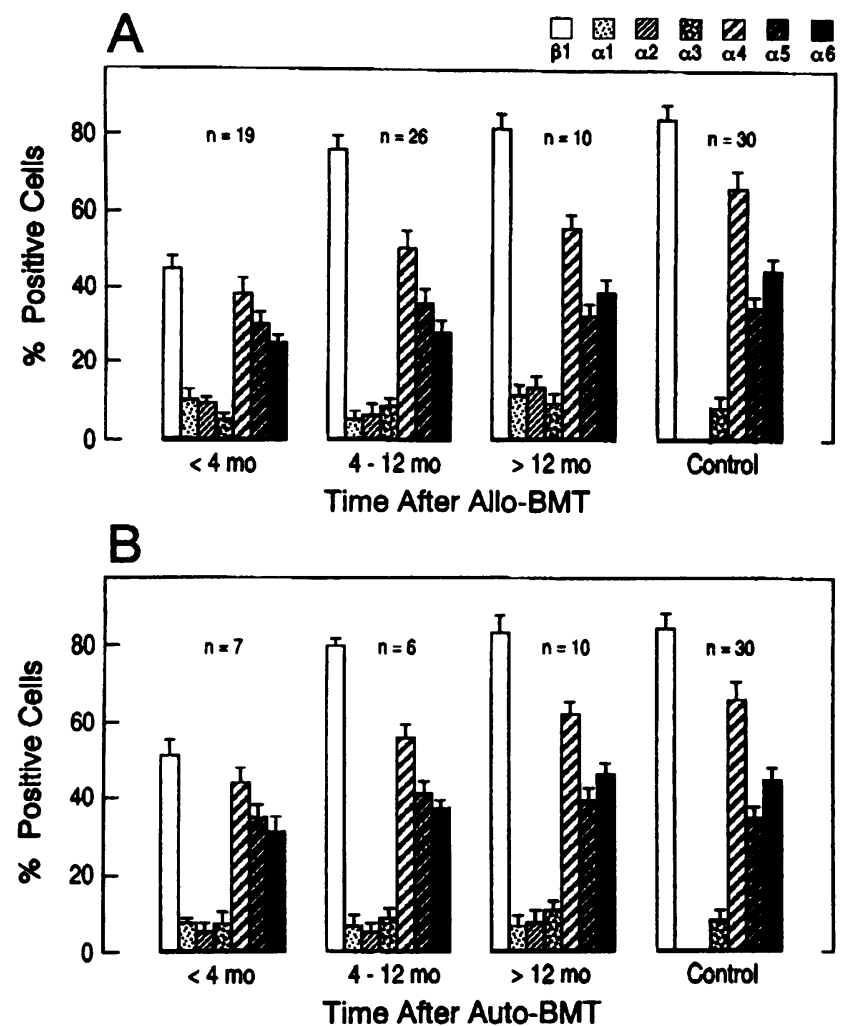

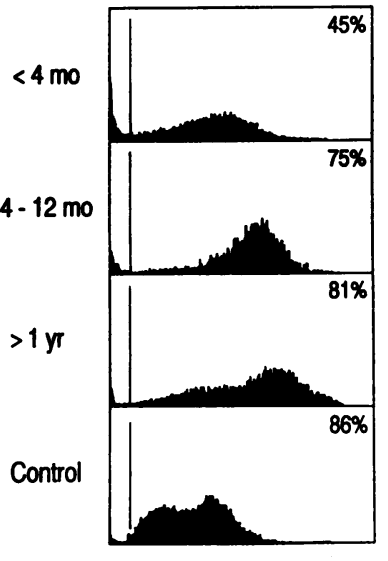

MFI

$86 \pm 25$

$94 \pm 28$

$102 \pm 35$

$72 \pm 23$
Figure 2. MFI of $\beta 1$ on lymphocytes at various points after allo-BMT.

Each bar represents the mean and SEM. Cytofluorographic analysis of $\beta 1$ expression of lymphocytes from representative patients at various points after allo-BMT and a control was performed on an Epics-C flow cytometer. Fluorescence intensity is represented on the horizontal axis on a three decade log scale, and cell number is on the vertical axis. Cells stained with mouse IgG1, as a negative control, were less than 5\% positive at each time point.

Figure 1. Expression of VLA antigens on lymphocytes after allo-BMT. Percent positive lymphocytes expressing $\beta$ chain and distinct $\alpha$ chains of VLA antigens at various periods post-allo-BMT $(A)$ and auto-BMT $(B)$. VLA $\beta 1$ and $\alpha 1-6$ expression on lymphocytes post allo-BMT and auto-BMT was examined at various time points. Lymphocytes from healthy volunteers were used as controls. Each bar represents the mean and SEM.

$200 \mu \mathrm{l}$ of media containing $10 \mu \mathrm{g} / \mathrm{ml}$ rabbit anti-mouse IgG (Jackson ImmunoResearch Labs, West Grove, PA) for $15 \mathrm{~min}$ at $37^{\circ} \mathrm{C}$. The reactions were terminated by the addition of $5 \mathrm{ml}$ of stop solution (cold PBS containing $10 \mathrm{mM} \mathrm{NaF}$ and $1 \mathrm{mM} \mathrm{Na}$ vanadate), and then solubilized in lysis buffer $(50 \mathrm{mM}$ Tris- $\mathrm{HCl}, \mathrm{pH} 8.0$ containing $1 \% \mathrm{NP}-$ 40, $150 \mathrm{mM} \mathrm{NaCl}, 5 \mathrm{mM}$ EDTA, $1 \mathrm{mM}$ PMSF, $10 \mathrm{mM}$ iodoacetamide, $10 \mathrm{mM} \mathrm{NaF}, 1 \mathrm{mM} \mathrm{Na}$ vanadate) for $15 \mathrm{~min}$ on ice. The cell lysates were separated on a $7.5 \%$ SDS-polyacrylamide gel under reducing conditions, and then transferred to nitrocellulose membrane, and blotted using ${ }^{125} \mathrm{I}$-labeled anti-phosphotyrosine mAb described previously (21). Autoradiographic exposure was performed using Kodak XAR film (Eastman Kodak Co., Rochester, NY).

Statistical analysis. Results are expressed as mean \pm SEM or mean \pm SD. Comparisons of groups were analyzed using the Mann-Whitney $\mathrm{U}$ test. Values of $P<0.05$ were considered significant.

\section{Results}

Expression of VLA antigens on lymphocytes post allo-BMT. To determine the functional properties of VLA proteins on lymphocytes post-T cell-depleted allo-BMT, we first examined the expression (\% positive cells) of VLA proteins comprising of distinct $\alpha$ chains $(\alpha 1-\alpha 6)$ and a $\beta 1$ chain (CD29). As summarized in Fig. $1, A$ and $B$, VLA $\beta 1$ as well as VLA $\alpha 4, \alpha 5$, and $\alpha 6$ expression was lower than normal controls during the first 4 mo both after allo-BMT and auto-BMT although such expressions were slightly higher in auto-BMT than in allo-BMT. How-

ever, this expression returned to normal levels by 4 mo after allo-BMT and auto-BMT. Although $\alpha 1$ and $\alpha 2$ were not expressed on lymphocytes from normal controls as reported previously (12), these antigens were expressed on lymphocytes at detectable levels $(5-15 \%)$ from patients after allo-BMT and auto-BMT. There was no difference in $\alpha 3$ expression on lymphocytes between post-allo-BMT and auto-BMT patients and normal controls. Since mean fluorescence intensity (MFI) reflecting density of antigen expression on the cell surfaces is also important in determining the function of these molecules, we next compared MFI of $\beta 1$ antigen expression of lymphocytes in patients after allo-BMT and in normal controls. As shown in Fig. 2, expression of VLA $\beta 1$ integrin on lymphocytes from a normal control was found as two peaks representing low and high density expression, while only one high peak was seen on lymphocytes from patients at any time points up to $1 \mathrm{yr}$ post-allo-BMT. Thereafter, two peaks representing a relatively small density difference (moderate to high) reappeared.

Impaired comitogenic effect of solid phase-immobilized anti-CD29 $\mathrm{mAb}$ on $C D 3-$ dependent $T$ cell proliferation postallo-BMT. In our earlier studies, we showed that VLA antigens not only mediate cell adhesion, but can synergize with the CD3 pathway to promote $T$ cell proliferation $(14,15,18,20)$. As shown in Fig. $3 A$, in a normal control anti-CD29 as well as other antibodies alone could not induce significant levels of $\mathrm{T}$ cell proliferation above background $(<1,000 \mathrm{cpm})$. In addition anti-CD3 alone could only induce minimal $\mathrm{T}$ cell proliferation. However, coimmobilization of anti-CD3 with anti-CD29 induced marked $\mathrm{T}$ cell proliferation. Anti-CD3 plus anti-CD2 or anti-CD26 also induced marked $\mathrm{T}$ cell proliferation as previously reported (31). In contrast, anti-L-selectin, which identifies a member of different class of adhesion molecule $(11,29)$, had virtually no comitogenic effect with anti-CD3. Since CD29 expression on lymphocytes from post-allo-BMT patients is higher than in normal controls, it was expected that comitogenic effect of anti-CD29 via the CD3 pathway might be stronger in post-allo-BMT lymphocytes than in normal control lymphocytes. However, as shown in Fig. $3 B$, in a representative patient 9 mo after T cell depleted allo-BMT, coimmobilization of anti- 


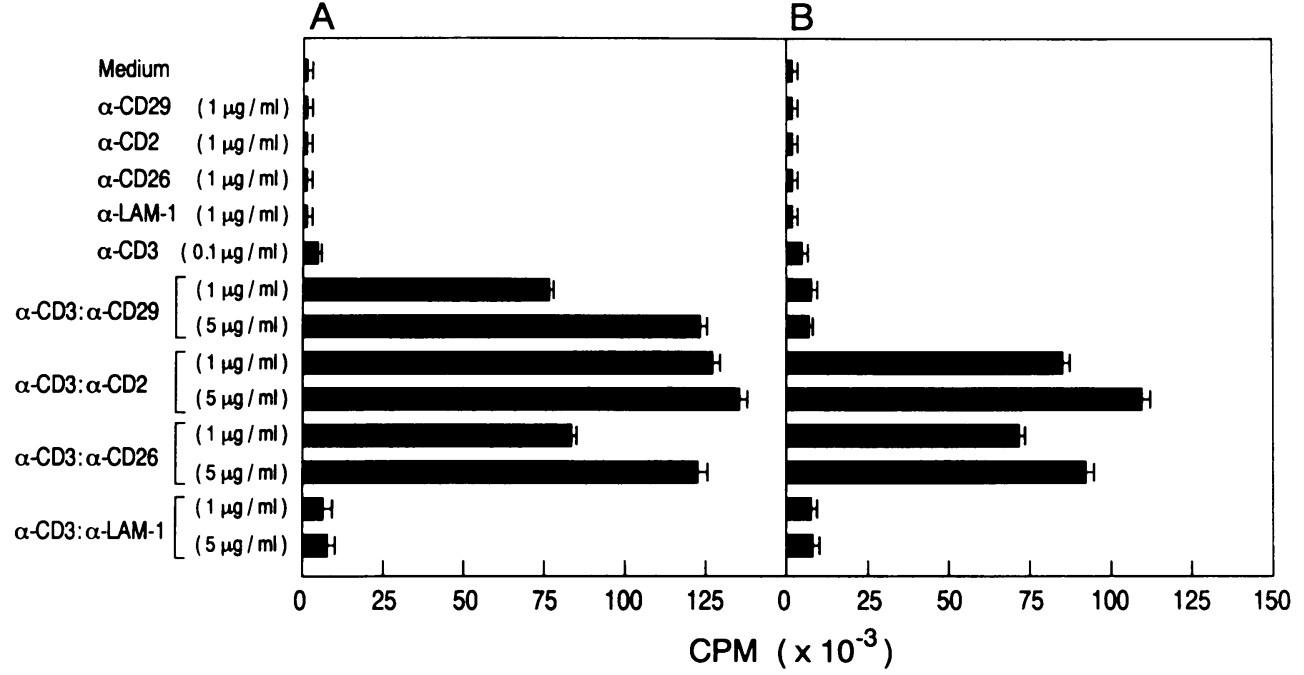

Figure 3. Impaired comitogenic effect of solid phase-immobilized anti-CD29 mAb on CD3-dependent $T$ cell proliferation after alloBMT. Purified lymphocytes ( 1 $\times 10 \%$ well) obtained from a healthy volunteer $(A)$ and a patient 9 mo after allo-BMT $(B)$ were stimulated in a serum-free medium with immobilized anti-CD3 $\mathrm{mAb}(0.1 \mu \mathrm{g} / \mathrm{ml})$ alone or coimmobilized anti-CD3 $\mathrm{mAb}$ and different $\mathrm{mAb}(1$ and $5 \mu \mathrm{g} / \mathrm{ml})$ against CD29, CD2, CD26, or Lselectin. After 3-d culture, proliferative response was assessed by $\left[{ }^{3} \mathrm{H}\right.$ thymidine incorporation. Results are expressed as the mean cpm of triplicate samples and SEM.
CD3 with anti-CD29 could not induce T cell proliferation despite the higher density of CD29 expression and a normal level of CD3 expression on their lymphocytes. Moreover, inability of the induction of $\mathrm{T}$ cell proliferation by coimmobilization of anti-CD3 plus anti-CD29 was observed at wide range of the dose of anti-CD29 mAb $(0.1-10 \mu \mathrm{g} / \mathrm{ml}$; data show only $1 \mu \mathrm{g} /$ $\mathrm{ml}$ and $5 \mu \mathrm{g} / \mathrm{ml}$ ). In contrast, in the case of other costimulatory combinations such as anti-CD3 plus either anti-CD2 or antiCD26, marked $\mathrm{T}$ cell proliferation could be induced similar to that observed in normal controls. It should be noted that CD26 expression on lymphocytes from this patient is lower than CD29 expression (60\% vs. $92 \%)$.

Fig. 4 summarizes the results of $\mathrm{T}$ cell proliferation studies obtained from normal controls and patients at various times after T cell-depleted allo- and auto-BMT. When lymphocytes were examined less than 4 mo after allo- or auto-BMT, any combination of anti-CD3 plus other mAbs could not induce $T$

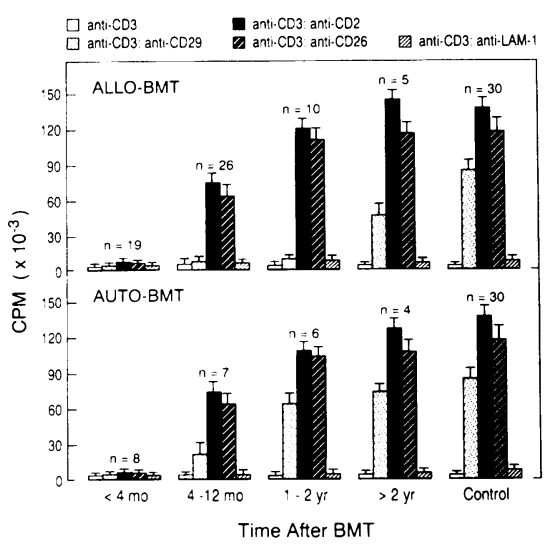

Figure 4. Summary of $\mathrm{T}$ cell proliferation after allo- and auto-BMT induced by coimmobilization of anti-CD3 mAb with different mAbs. Samples obtained from patients after allo-BMT $(n=60)$, after autoBMT $(n=25)$, and healthy volunteers $(n=30)$ were analyzed as described in Fig. 2. Immobilized anti-CD3 mAb was used at $0.1 \mu \mathrm{g} / \mathrm{ml}$ and other $\mathrm{mAb}$ were used at $1 \mu \mathrm{g} / \mathrm{ml}$. Each bar represents the mean $\mathrm{cpm}$ and SEM in each group calculated from the individual mean cpm in triplicate assays. cell proliferation. This may be due to dysfunction of CD3mediated signal transduction. However, when lymphocytes were examined in patients 4 mo after allo- and auto-BMT, CD3:CD2 or CD3:CD26-mediated T cell proliferation was considerably improved and almost reached normal levels by $1 \mathrm{yr}$. In contrast, delayed recovery of CD3:CD29-mediated $T$ cell proliferation was observed. Although as shown in Fig. 4, this impaired $\mathrm{T}$ cell proliferation recovered within $1 \mathrm{yr}$ in patients after auto-BMT, it lasted for more than $2 \mathrm{yr}$ in patients after allo-BMT.

Impaired comitogenic effect of solid-phase immobilized ECM on CD3-dependent $T$ cell proliferation post-allo-BMT. As we reported previously $(14,20)$, ligation of anti-CD29 appears to mimic interaction between extracellular matrix proteins and VLA antigens expressed on T cells and coimmobilization of ECM with anti-CD3 can result in T cell proliferation. As shown in Fig. $5 \mathrm{~A}$, in a normal control, neither anti-CD3 alone nor $\mathrm{ECM}$ such as $\mathrm{CO}, \mathrm{LN}$, and $\mathrm{FN}$ alone, resulted in minimal $\mathrm{T}$ cell proliferation. However, coimmobilization of anti-CD3 with ECMs induced marked $\mathrm{T}$ cell proliferation in a dose-dependent fashion. In contrast, as expected from the results of Fig. $3 \mathrm{~B}$, an impaired CD3: ECM-mediated $\mathrm{T}$ cell proliferation was also observed in a representative patient $9 \mathrm{mo}$ after $\mathrm{T}$ cell depleted allo-BMT (Fig. $5 \mathrm{~B}$ ). The defect of costimulation by coimmobilization of anti-CD3 $\mathrm{mAb}$ and ECMs were observed even in the higher doses of ECMs ( 10 and $25 \mu \mathrm{g} / \mathrm{ml}$ : data not shown). Fig. 6 summarizes the results of $T$ cell proliferation studies obtained from normal controls. $\mathrm{T}$ cell-depleted allo- and autoBMT patients. As shown in Fig. 6, this impairment as in the case of costimulation by coimmobilization of anti-CD3 and antiCD29 mAbs, also lasted longer in patients after allo-BMT than after auto-BMT. Of interest, when different ECMs were examined, CD3:LN-mediated $\mathrm{T}$ cell proliferation recovered earlier than CD3:CO or CD3:FN mediated $\mathrm{T}$ cell proliferation in both patient populations.

Normal or increased adhesion of lymphocytes to FN after allo-BMT. Prolonged impaired VLA-mediated T cell costimulation via the CD3 pathway after allo-BMT appears to be due to either lowered avidity between VLA proteins and ECM. or some defects in the process of signal transduction through VLA proteins on $\mathrm{T}$ cells. Since the majority of $\mathrm{T}$ lymphocytes prefer- 


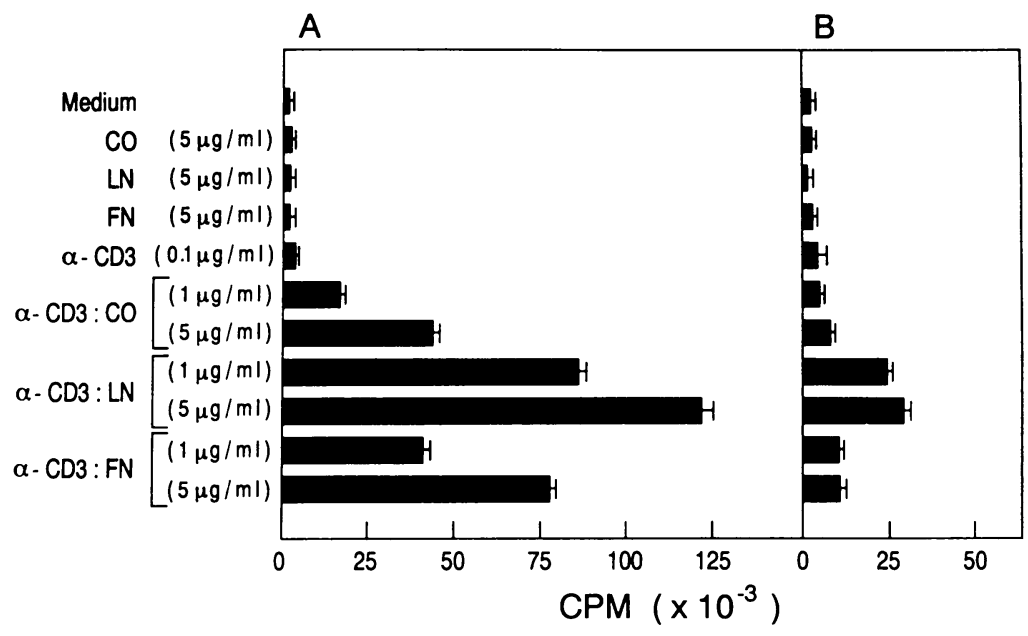

Figure 5. Impaired comitogenic effect of solid phaseimmobilized ECM on CD3-dependent $\mathrm{T}$ cell proliferation post allo-BMT. Purified lymphocytes $\left(1 \times 10^{5} /\right.$ well $)$ obtained from a healthy volunteer $(A)$ and a patient 9 mo after allo-BMT $(B)$ were stimulated in serum-free medium with immobilized anti-CD3 $\mathrm{mAb}(0.1 \mu \mathrm{g} / \mathrm{ml})$ alone or coimmobilized anti-CD3 $\mathrm{mAb}$ and different ECM ( 1 and $5 \mu \mathrm{g} / \mathrm{ml})$ such as CO, LN, or FN. After 3 $\mathrm{d}$ culture, proliferative response was assessed by $\left[{ }^{3} \mathrm{H}\right]-$ thymidine incorporation. Results are expressed as the mean cpm of triplicate samples and SEM. entially express FN receptors (VLA-4 and VLA-5), we examined the binding of lymphocytes to fibronectin-coated plates using ${ }^{51} \mathrm{Cr}$-labeled lymphocytes from normal controls and patients 4-12 mo after T cell-depleted allo-BMT. As shown in Fig. 7, the specific binding of lymphocytes to fibronectin in normal controls $(n=5)$ was $7.4 \pm 0.8 \%$, compared to $9.8 \pm 3.5 \%$ in patients after allo-BMT $(n=5)$. The specific binding of lymphocytes to the FN-coated plate was almost totally abrogated by the addition of anti-CD29 mAb as well as the addition of the mixture of both VLA-5 and VLA4 but not other VLA antibodies in both groups (data not shown), indicating that its binding is specifically mediated by VLA-5 and VLA-4 expressed on lymphocytes. Although there was no statistical difference in the specific binding between two groups, apparently higher specific binding of lymphocytes to FN (22.6\%) was noted in one patient $8 \mathrm{mo}$ after allo-BMT. It should be noted that even in this patient, $\mathrm{FN}$-induced $\mathrm{T}$ cell proliferation via the CD3 pathway was markedly impaired (data not shown). These results suggest that lymphocytes after $\mathrm{T}$ cell-depleted allo-BMT have normal or increased adhesive capacities to ECM, but may have some defect(s) in the process of costimulatory signaling process through VLA proteins.

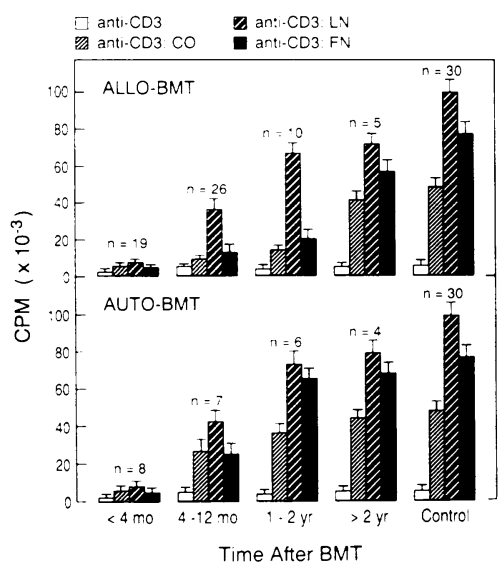

Figure 6. Summary of $\mathrm{T}$ cell proliferation after allo- and auto-BMT induced by coimmobilization of anti-CD3 mAb with different ECM. Samples obtained from patients after allo-BMT $(n=60)$, after auto-BMT $(n=25)$, and healthy volunteers $(n=30)$ were analyzed as described in Fig. 4. Immobilized antiCD3 mAb was used at $0.1 \mu \mathrm{g} / \mathrm{ml}$ and ECM were used at $5 \mu \mathrm{g} / \mathrm{ml}$. Each bar represents the mean cpm and SEM in each group calculated from the individual mean cpm in triplicate assays.
Normal or increased VLA-induced tyrosine-phosphorylation of lymphocytes after allo-BMT. We have recently shown that ligation of VLA antigen on T cells by anti-VLA $\beta 1$ or $\alpha 4 \mathrm{mAb}$ stimulates tyrosine phosphorylation of a $105-\mathrm{kD}$ protein ( $\mathrm{pp} 105$ ) (21). Since tyrosine phosphorylation on cellular proteins is an early and obligatory event in the activation of $\mathrm{T}$ cells (32-37) this phosphorylation event may play a role in the transduction of activation signals through this molecule. Therefore, we next attempted to determine whether a pp 105 tyrosine phosphorylation was observed in lymphocytes obtained from a normal control and three patients 6 mo following $\mathrm{T}$ cell-depleted alloBMT. For this purpose, the crosslinking of VLA $\beta 1$ (CD29) with a specific mAb (anti-4B4) was used to induce the ppl05, and anti-phosphotyrosine $\mathrm{mAb}$ was used to detect this molecule. As shown in Fig. 8, densitometric analysis showed that increased ppl05 was observed in all three patients studied compared to that observed in the normal control. It should be noted that in addition to pp105 tyrosine phosphorylated protein, an approximately $120-\mathrm{kD}$ protein is also tyrosine phosphorylated that is less markedly induced in both normal lymphocytes and patients' lymphocytes. Our results indicate that tyrosine phos-

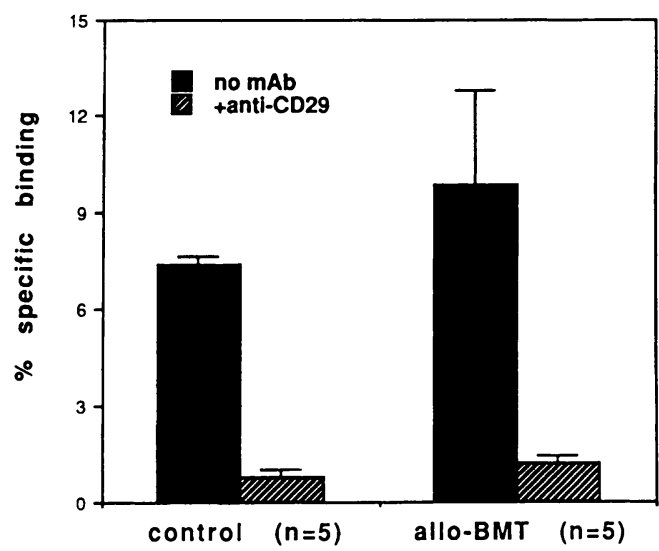

Figure 7. Adhesion of lymphocytes to the FN-coated plate after alloBMT. Cell adhesion assays of ${ }^{51} \mathrm{Cr}$-labeled purified lymphocytes from patients after allo-BMT $(n=5)$ and healthy volunteers $(n=5)$ were performed in triplicate with or without addition of anti-CD29 mAb. The data was expressed as the mean percent specific binding and SD. 


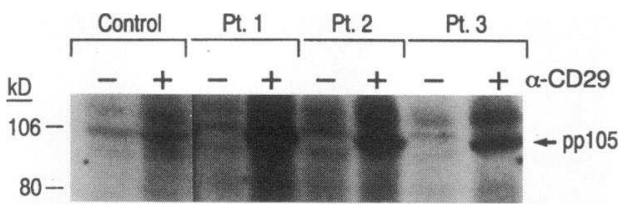

Figure 8. Induction of pp105 tyrosine phosphorylation in peripheral lymphocytes from a normal control and three patients $6 \mathrm{mo}$ after alloBMT. Monocyte depleted lymphocyte populations obtained from 3 patients 6 mo after allo-BMT and a normal control were incubated with anti-4B4 for $15 \mathrm{~min}$ at $4^{\circ} \mathrm{C}$, followed by crosslinking with anti-mouse Ig for $15 \mathrm{~min}$ at $37^{\circ} \mathrm{C}$. The tyrosine phosphorylation of pp105 was detected by anti-phosphotyrosine antibody immunoblotting.

phorylation of a 105 - and $120-\mathrm{kD}$ protein is not impaired in lymphocytes after allo-BMT, suggesting that other defects in VLA-mediated signals may be present in such patients.

\section{Discussion}

In this study, we showed that $\mathrm{T}$ cells obtained from post $\mathrm{T}$ celldepleted allo-BMT patients exhibited decreased proliferative response triggered by immobilized anti-CD3 plus ECMs or antiCD29 mAb compared with T cells from normal controls. Such impaired VLA-mediated costimulation persisted for a prolonged period (more than $2 \mathrm{yr}$ ) after $\mathrm{T}$ cell depleted allogeneic BMT. In contrast, $\mathrm{T}$ cells from auto-BMT patients initially showed low response, but later gained normal levels of proliferation within $1 \mathrm{yr}$ after transplantation.

Previous studies of immune function after allogeneic BMT have documented a variety of in vitro $T$ cell abnormalities after engraftment (6-10). More recently we evaluated cells from patients without GVHD who have received donor marrow depleted of CD6 + T lymphocytes (24) and reported that stimulation by either nonspecific lectin (PHA) or antibodies to CD2 (anti-T11 $1_{2}+$ anti-T11 $1_{3}$ ) resulted in decreased levels of $\mathrm{T}$ cell proliferation compared with controls for over 12 mo after BMT. Lum and colleagues (38) reported that the signal transduction response mediated by the $\mathrm{CD} 3$-antigen receptor as measured by calcium flux is defective early after both autologous and allogeneic BMT and such defective anti-CD3 induced calcium flux returned to the almost normal levels after $1 \mathrm{yr}$ post-BMT. Thus, the CD3 pathway for activating $\mathrm{T}$ cells appears to be generally disturbed both in allo- and auto-BMT patients in a relatively early phase of post-BMT.

It is not conclusive at present whether the prolonged VLAmediated signaling defect in $\mathrm{T}$ cells observed after $\mathrm{T}$ cell depleted allo-BMT can be generalized to all allo-BMT because there remains the possibility that the difference in VLA function between $\mathrm{T}$ cell depleted allo- and auto-BMT comes from the difference between absence and presence of mature $T$ cells included in marrow grafts, but not from the difference between allo- and auto-BMT. However, the above possibility appears to be less likely for the following reasons. Compared with the findings of other studies characterizing immune reconstitution after allogeneic transplantation with non-T cell-depleted marrow grafts (39), we observed no significant delay in the recovery of normal numbers of $T$ lymphocytes in our patients (24). The numbers of CD3 + T cells increase gradually after BMT, becoming the predominant lymphoid population by $6 \mathrm{wk}$ and reaching control levels after 10 to 12 wk (24). Moreover, our recent studies of phenotypic comparison between T cell-depleted allogeneic BMT patients and auto-BMT patients showed that there are virtually no significant differences in $\mathrm{T}$ cell subsets between these groups but inverted CD4/CD8 ratio was continuously observed in both groups over 2 yr which is in contrast to the CD4/ CD8 ratio of normal individuals (40). Moreover, as shown in Fig. $1, A$ and $B$, there are no significant differences of the expression of VLA- $\beta$ chain and VLA- $\alpha$ chains on lymphocytes from T cell-depleted allo-BMT and auto-BMT patients' group. Others reported that although the recovery of various $\mathrm{T}$ cell proliferative responses were more delayed in recipients of $T$ cell-depleted marrow grafts, compared to non-purged allo-BMT patients, auto-BMT and normal controls, there are no significant differences in such $\mathrm{T}$ cell responses after one year between these groups (39). Moreover, as shown in our results, $T$ cell costimulation by $\mathrm{CD} 2$ or CD26 molecule via the CD3 pathway was rapidly improved and almost reached normal levels by 1 yr both in our T cell purged allo-BMT and auto-BMT patients. However, the prolonged impairment of the VLA-mediated costimulation via the CD3 pathway was still specifically observed in our $\mathrm{T}$ cell purged allo-BMT patients. Taken together, these results strongly suggest that the prolonged impairment of the VLA mediated T cell costimulation post-allo-BMT appears to come from insufficient education of donor's lymphoid stem cells in recipient thymus and/or thymus equivalent. Further intensive studies comparing VLA-mediating signaling events between $\mathrm{T}$ cell-depleted and non-T cell-depleted allo-BMT will be required to clarify whether our finding is common to all alloBMT patients.

The reaction of specific peptide antigen or antibodies against the antigen specific $\mathrm{T}$ cell receptor (TcR)/CD3 complex is generally unable to induce $\mathrm{T}$ cell proliferation and lymphokine secretion on its own (41). Rather, T cells require a second signal, which is referred to as costimulation, and this activity can be provided by a number of accessory molecules expressed on the T cell surface such as CD28, LFA1, CD29/VLA, and CD26 $(14,21,31,42-45)$. Although physiological meaning of redundancy of costimulatory molecules is not fully understood, it has been speculated that $T$ cells might use different sets of these molecules dependent upon their functional subsets, opposing cells with which they interact, or places they must be activated. Our observation that defective costimulation of $\mathrm{T}$ cells was relatively restricted to VLA-mediated pathway in the late phase of T cell-depleted allo-BMT further support the differential regulation of $\mathrm{T}$ cell costimulation. Immunodeficiency after autologous BMT is generally regarded to be less and milder compared to that after allo-BMT $(1,2,46)$. Especially, cytomegalovirus infections are much less common after autologous or syngeneic BMT than after allo-BMT (46). There may be a possibility that the prolonged impairment of VLA-mediated $\mathrm{T}$ cell proliferation after $\mathrm{T}$ cell-depleted allo-BMT may reflect at least in part, the immunoincompetent status found in such patients.

What are mechanisms for the defective $T$ cell costimulation by very late activation (VLA) antigens? In both T cell-depleted allo-BMT and auto-BMT patients, percentages of expression of VLA $\beta 1$, as well as VLA $\alpha 4, \alpha 5$, and $\alpha 6$ were lower than those in normal controls during the first 3 mo after BMT, but they returned to normal range by $4 \mathrm{mo}$. In addition, mean density of VLA $\beta 1$ was found to be significantly higher on T cells from patients at any time points after BMT. Moreover, patients' $T$ cells normally or rather more strongly adhered to ECM-coated plates even late period of post-BMT. Thus, impairment of VLA- 
mediated costimulation can not be attributed to poor expression or poor binding capacity of VLAs. Defective site, if any, may be located in the signaling pathway after an event in which VLAs interacted with their ligands. The reason why the CD3:laminin induced $T$ cell costimulation recovers relatively faster than other CD3:ECMs induced $\mathrm{T}$ cell proliferation in allo-BMT patients is not clear at present. Since it is reported that there are many ill-characterized laminin receptors in addition to the integrin family of antigens (47), it may be possible that signal inducing capacity of VLA-unrelated laminin receptors on $\mathrm{T}$ cells may recover faster than that of VLA-receptors.

Although T cell-depleted allo-BMT is a model to study recapitulation of $\mathrm{T}$ cell ontogeny in adults, relative $\mathrm{T}$ cell immuno-incompetence of human neonates appears to be somewhat different from the $\mathrm{T}$ cell immuno-incompetence of $\mathrm{T}$ celldepleted allo-BMT. Because we recently showed that in both $\mathrm{T}$ cell-depleted allo-BMT and auto-BMT patients, CD4 + CD45RA + naive, and CD4 + CD29+ memory T cells were markedly decreased during the first 24 mo after BMT (40), whereas in neonates, their T cells include few CD29 memory $T$ cells and consist almost exclusively of the CD45RA naive $T$ cells (48).

Recent studies have documented that tyrosine phosphorylation on cellular proteins is an early and obligatory event in the activation of $T$ cells (32-37). More recently, we showed that engagement of VLA molecules by specific antibodies or by their ligands rapidly stimulated tyrosine phosphorylation of a $105-\mathrm{kD}$ protein in $\mathrm{T}$ cells (21). Tyrosine phosphorylation events triggered via VLAs have also been described in KB carcinoma cells and NIH 3T3 fibroblasts. Cross-linking of VLA-3 in KB cells leads to tyrosine phosphorylation of proteins of $120 \mathrm{kD}$, and adhesion and spreading on fibronectin or on anti- $\beta 1$ antibodies leads to rapid tyrosine phosphorylation of a protein of similar size $(49,50)$. More recently, it was demonstrated that these proteins are identical to $\mathrm{pp} 125^{\mathrm{FAK}}$, a structurally distinct protein-tyrosine kinase associated with focal adhesion (51). Our preliminary results showed that pp105 is not the same protein as pp125 $5^{\mathrm{FAK}}$ (our unpublished data by Y. Nojima et al.). It is likely that pp105-125 $5^{\mathrm{FAK}}$ may be components of signal transduction pathway responsible for the transmission of signals from the cell surface integrins into the cell. Normal or even enhanced tyrosine phosphorylation of pp105-120 in $\mathrm{T}$ cells from allo-BMT patients which are defective in proliferative response stimulated with anti-CD3 plus ECMs or anti-CD29 were well correlated with the normal or enhanced binding capacity of these $\mathrm{T}$ cells to FN-coated plates, implying that the impaired costimulation by VLAs is not attributed to this biochemical event. Although it is not clear whether tyrosine kinase activation event is actually involved in the comitogenic proliferative signals after the engagement of the VLA molecules, our data suggest that there are some other defects in the process of VLA-mediated signal transduction in the downstream of pp105.

Further studies will be undertaken to determine the precise molecular defect of VLA-mediated T cell costimulatory activity which was specifically observed in allo-BMT patients.

\section{Acknowledgments}

We thank Thanh Pham, John Daley, and Herbert Levine for technical assistance and thank Lisa Warren for her secretarial assistance.

This work was supported by National Institutes of Health grants AI12609, AI29530, and AR33713.

\section{References}

1. Thomas, E. D. 1983. Marrow transplantation for malignant diseases. $J$. Clin. Oncol. 1:517-531.

2. Bortin, M. M., and A. A. Rimm. 1986. Increasing utilization of bone marrow transplantation. Transplantation (Baltimore). 42:229-234.

3. Pirsch, J. D., and D. G. Maki. 1986. Infectious complications in adults with bone marrow transplantation and $\mathrm{T}$ cell depletion of donor marrow. Increased susceptibility to fungal infections. Ann. Intern. Med. 104:619-631.

4. Atkinson, K., R. Storb, R. L. Prentice, P. L. Weiden, R. P. Witherspoon, K. Sullivan, D. Noel, and E. D. Thomas. 1979. Analysis of late infections in 89 long term survivors of bone marrow transplantation. Blood. 63:720-731.

5. Meyers, J. 1986. Infection in bone marrow transplant recipients. Am. J. Med. 81:27-38.

6. Witherspoon, R. P., L. G. Lum, R. Storb, and E. D. Thomas. 1982. In vitro regulation of immunoglobulin synthesis after human marrow transplantation. II. Deficient $T$ and non-T lymphocyte function with 3-4 months of allogeneic, syngeneic, or autologous marrow grafting for hematologic malignancy. Blood. 59:844-850.

7. Mori, T., M. S. Tsoi, S. Gillis, E. Santos, E. D. Thomas, and R. Storb. 1983. Cellular interactions in marrow-grafted patients. 1. Impairment of cellmediated lympholysis associated with graft-vs-host disease and the effect of interleukin 2. J. Immunol. 130:712-716.

8. Korsmeyer, S. J., G. J. Elfenbaum, C. K. Goldman, S. L. Marshall, and T. A. Waldmann. 1982. B cell, helper T cell and suppressor $\mathrm{T}$ cell abnormalities contribute to disordered immunoglobulin synthesis in patients following bone marrow transplantation. Transplantation (Baltimore). 33:184-190.

9. Welte, K., C. A. Keever, J. Levick, M. Bonila, V. J. Merluzzi, R. Mertelsmann, R. Evans, and R. J. O'Reilly. 1987. Interleukin-2 production and response to interleukin 2 by peripheral blood mononuclear cells from patients after bone marrow transplantation: II. Patients receiving soybean lectin-separated and T cell depleted marrow. Blood. 70:1595-1603.

10. Zander, A. R., J. M. Reyben, D. Johnston, L. Vellekoop, K. A. Dicke, J. C. Yan, and E. M. Hersh. 1985. Immune recovery following allogeneic bone marrow transplantation. Transplantation (Baltimore). 40:177-183.

11. Springer, T. A. 1990 . Adhesion receptors of the immune system. Nature (Lond.). 346:425-434.

12. Hemler, M. E. 1990. VLA proteins in the integrin family: structures, functions, and their role on leukocytes. Annu. Rev. Immunol. 8:365-400.

13. Hynes, R. O. 1987. Integrins: a family of cell surface receptors. Cell. 48:549.

14. Matsuyama, T., A. Yamada, J. Kay, K. M. Yamada, S. K. Akiyama, S. F. Schlossman, and C. Morimoto. 1989. Activation of CD4 cells by fibronectin and anti-CD3 antibody. A synergistic effect mediated by the VLA- 5 fibronectin receptor complex. J. Exp. Med. 170:1133-1148.

15. Dang, N. H., Y. Torimoto, S. F. Schlossman, and C. Morimoto. 1990 Human CD4 helper T cell activation: functional involvement of two collagen receptors 1F7 and VLA integrin family. J. Exp. Med. 172:649-652.

16. Shimizu, Y., G. A. van Seveter, K. J. Horgan, and S. Shaw. 1990. Costimulation of proliferative responses of resting CD4 $+\mathrm{T}$ cells by the interaction of VLA-4 and VLA-5 with fibronectin or VLA-6 with laminin. J. Immunol. 145:5967.

17. Davis, L. S., N. Oppenheimer-Marks, J. L. Bednarczyk, B. W. McIntyre, and P. E. Lipsky. 1990. Fibronectin promotes proliferation of naive and memory T cells by signalling through both the VLA-4 and VLA- 5 integrin molecules. $J$. Immunol. 148:785-793.

18. Nojima, Y., M. J. Humphries, A. P. Mould, A. Komoriya, K. M. Yamada, S. F. Schlossman, and C. Morimoto. 1990. VLA-4 mediates CD3-dependent CD4 + T cell activation via the CS1 alternatively spliced domain of fibronectin J. Exp. Med. 172:1185-1192.

19. Damle, N. K., and A. Aruffo. 1991. Vascular cell adhesion molecule 1 induces T-cell antigen receptor-dependent activation of CD4 T lymphocytes. Proc. Natl. Acad. Sci. USA. 88:6403-6407.

20. Yamada, A., Y. Nojima, K. Sugita, N. H. Dang, S. F. Schlossman, and C. Morimoto. 1991. Crosslinking of VLA/CD29 molecule has a co-mitogenic effect on CD4 cell activation via CD3-TcR pathway in a serum-free culture system. Eur. J. Immunol. 21:319-325.

21. Nojima, Y., D. R. Rothstein, K. Sugita, S. F. Schlossman, and C. Morimoto. 1992. Ligation of VLA-4 on T cells stimulates tyrosine phosphorylation of a 105-kD protein. J. Exp. Med. 175:1045-1053.

22. Utsumi, K., M. Sawada, S. Narumiya, J. Nagamine, T. Sakata, S. Iwagami, Y. Kita, H. Teraoka, H. Hirano, M. Ogata, T. Hamaoka, and H. Fujiwara. 1991. Adhesion of immature thymocytes to thymic stromal cells through fibronectin molecules and its significance for the induction of thymocyte differentiation. Proc. Natl. Acad. Sci. USA. 88:5685-5689.

23. Cardarelli, P. M., and M. D. Pierschbacher. 1986. T-lymphocyte differentiation and the extracellular matrix: identification of a thymocyte subset that attaches specifically to fibronectin. Proc. Natl. Acad. Sci. USA. 83:2647-2651.

24. Soiffer, R. J., L. Bosserman, C. Murray, K. Cochran, J. Daley, and J. 
Ritz. 1990. Reconstitution of T-cell function after CD6-depleted allogeneic bone marrow transplantation. Blood. 75:2076-2084.

25. Rohatiner, A., R. Gelber, S. F. Schlossman and J. Ritz. 1986. Depletion of $\mathrm{T}$ cells from human bone marrow using monoclonal antibodies and rabbi complement: A quantitive and functional analysis. Transplantation (Baltimore). 42:73-80.

26. Reinherz, E. L., O. Acuto, M. Fabbi, A. Bensussan, C. Milanese, H. D. Royer, S. C. Meuer, and S. F. Schlossman. 1984. Clonotypic surface structure on human T lymphocytes: Functional and biochemical analysis of the antigen receptor complex. Immunol. Rev. 81:95-129.

27. Morimoto, C., Y. Torimoto, G. Levinson, C. E. Rudd, M. Schrieber, N. H Dang, N. L. Letvin, and S. F. Schlossman. 1989. 1F7, a novel cell surface molecule, involved in helper function of CD4 cells. J. Immunol. 143:3430-3439.

28. Morimoto, C., N. L. Letvin, A. W. Boyd, M. Hagan, H. Brown, M Kormacki, and S. F. Schlossman. 1985. The isolation and characterization of the human helper T cell subset. J. Immunol. 134:3762.

29. Reinherz, E. L., C. Morimoto, K. A. Fitzgerald, R. E. Hussey, J. F. Daley, and S. F. Schlossman. 1982. Heterogeneity of human T4+ inducer T cells as defined by a monoclonal antibody with Qa-like pattern of reactivity. J. Immunol. 128:463-468.

30. Morimoto, C., A. D. Steinberg, N. L. Letvin, M. Hagan, T. Takeuchi, J. Daley, H. Levine, and S. F. Schlossman. 1987. A defect of immunoregulatory T cell subsets in systemic lupus erythematosus patients demonstrated with anti-2H4 antibody. J. Clin. Invest. 79:762-768.

31. Dang, N. H., Y. Torimoto, K. Deusch, S. F. Schlossman, and C. Morimoto 1990. Comitogenic effect of solid-phase immobilized anti-1F7 on human CD4 T cell activation via CD3 and CD2 pathways. J. Immunol. 144:4092-4100.

32. Klausner, R. D., and L. E. Samelson. 1991. T cell antigen receptor activation pathways: the tyrosine kinase connection. Cell. 64:875.

33. Samelson, L. E., M. D. Patel, A. M. Weissman, J. B. Harford, and R. D. Klausner. 1986. Antigen activation of murine $T$ cells induces tyrosine phosphorylation of a polypeptide associated with the $\mathrm{T}$ cell antigen receptor. Cell. 46:10831090.

34. Weiss, A., G. Koretsky, R. C. Schatzman, and T. Kadlecek. 1991. Functional activation of the $T$ cell antigen receptor induces tyrosine phosphorylation of phospholipase C-r-1. Proc. Natl. Acad. Sci. USA. 88:5484-5488.

35. Secrist, J. P., L. Karnitz, and R. T. Abraham. 1991. T cell antigen receptor ligation induces tyrosine phosphorylation of phospholipase C- $\gamma 1$. J. Biol. Chem. 266:12135-12139.

36. June, C. H., M. C. Fletcher, J. A. Ledbetter, G. L. Schieven, J. N. Siegel, A. F. Phillips, and L. E. Samelson. 1990. Inhibition in tyrosine phosphorylation prevented T cell receptor-mediated signal transduction. Proc. Natl. Acad. Sci. USA. 87:7722-7726.

37. Mustelin, T., K. M. Coggeshall, N. Isakov, and A. Altman. 1990. T cell antigen receptor-mediated activation of phospholipase $\mathrm{C}$ requires tyrosine phosphorylation. Science (Wash. DC). 247:1584-1587.

38. Yamagami, M., P. W. McFadden, S. M. Koethe, V. Ratanatharathorn, and L. G. Lum. 1990. Failure of T cell receptor-anti-CD3 monoclonal antibody interaction in $\mathrm{T}$ cells from marrow recipients to induce increases in intracellula ionized calcium. J. Clin. Invest. 86:1347-1351.

39. Keaver, C. A., T. N. Small, N. Flomenberg, G. Heller, K. Pekle, P. Black, A. Pecorda, A. Gillo, N. A. Kernan, and R. J. O'Relly. 1989. Immune reconstitution following bone marrow transplantation: comparison of recipient of T-cell depleted marrow with recipients of conventional marrow grafts. Blood. 73:1340-1350.

40. Sugita, K., R. J. Soiffer, C. Murray, S. F. Schlossman, J. Ritz, and C. Morimoto. 1994. Phenotype and reconstitution of immunoregulatory T cell subsets after $\mathrm{T}$ cell depleted allogeneic and autologous bone marrow transplantation. Transplant. 57:1465-1473.

41. Weaver, C. T., and E. R. Unanue. 1990. The costimulatory function of antigen-presenting cells. Immunol. Today. 11:49-55.

42. Linsley, P. S., W. Brady, L. Grosmaire, A. Aruffo, N. K. Damle, and J. Ledbetter. 1991. Binding of the B cell activation antigen B7 to CD28 costimulates T cell proliferation and interleukin-2 mRNA accumulation. J. Exp. Med. 173:721 730.

43. van Noesel, C., F. Miedema, M. Brouwer, M. A. deRie, L. A. Aarden, and R. A. W. van Lier. 1988. Regulatory properties of LFA-1 $\alpha$ and $\beta$ chains in human T lymphocytes activation. Nature (Lond.). 333:850-852.

44. van Seventer, G. A., Y. Shimizu, K. J. Horgan, and S. Shaw. 1990. The LFA-1 ligand ICAM-1 provides an important costimulatory signal for $\mathrm{T}$ cell receptor-mediated activation of resting T cells. J. Immunol. 144:4579-4586.

45. Geppert, T. D., L. S. Davis, H. Gur, M. C. Watcholtz, and P. E. Lipsky 1990. Accessory cell signals involved in $\mathrm{T}$ cell activation. Immunol. Rev. 117:566.

46. Wingard, J. R. 1990. Advances in the management of infectious complications after bone marrow transplantation. Bone Marrow Transplant. 6:371-383.

47. Mecham, R. P. 1991. Laminin receptors. Annu. Rev. Cell Biol. 7:71-91.

48. Sanders, M. E., M. W. Makgoba, and S. Shaw. 1988. Human naive and memory $\mathrm{T}$ cells: reinterpretation of helper-inducer and suppressor-inducer subsets Immunol. Today. 9:195-199.

49. Kornberg, L. J., H. S. Earp, C. E. Turner, C. Prockop, and R. L. Juliano. 1991. Signal transduction by integrins: increased protein tyrosine phosphorylation caused by clustering of $\beta 1$ integrins. Proc. Natl. Acad. Sci. USA. 88:8392-8396.

50. Guan, J. L., J. J. Trevithick, and R. O. Hynes. 1991. Fibronectin/integrin interaction induces tyrosine phosphorylation of a $120 \mathrm{kba}$ protein. Cell Regul. 2:951-964.

51. Schaller, M. D., C. A. Borgman, B. S. Cobb, R. R. Vines, A. B. Reynold, and J. T. Parsons. 1992. pp125 ${ }^{\mathrm{FAK}}$, a structurally distinctive protein-tyrosine kinase associated with focal adhesions. Proc. Natl. Acad. Sci. USA. 89:5192-5196. 